\title{
What Happened to the Prevention of Child Maltreatment During COVID-19? A Yearlong into the Pandemic Reflection
}

\author{
Carmit Katz ${ }^{1}$
}

Accepted: 12 April 2021 / Published online: 28 April 2021

(c) The Author(s), under exclusive licence to Springer Nature Switzerland AG 2021

In March 2020, when COVID-19 was acknowledged as a worldwide pandemic, many countries dedicated their efforts to mitigate the virus and its negative health outcomes. One of the most frequent solutions was forced lockdowns, which was found to be beneficial in decreasing the spread of the virus. Today, after a year of international efforts to diminish the virus, we are at a stage where we can see the impact of these measures on children during COVID-19. Specifically, we now need to reflect on what happened to the prevention of child maltreatment $(\mathrm{CM})$ during this time.

There is an accumulation of knowledge with respect to the dramatic decrease of CM reports to formal systems worldwide during the COVID-19 pandemic. Moreover, researchers have been stressing that this decrease should not be attributed to an increase in the safety of children but rather due to the adverse impact of the lockdown on the system's ability to see and protect children (e.g., Baron et al., 2020; Katz \& Cohen, 2020). In addition, there is growing evidence that during COVID-19, various CM risk factors significantly increased (Conrad-Hiebner \& Byram, 2020; Proulx et al., 2021; Rodriguez et al., 2020; Wu \& Xu, 2020), such as parental job loss (Lawson et al., 2020), parental social isolation (Lee et al., 2021), and mental health issues (Russell et al., 2020). Adding to this, parental stress was found to be a major CM risk factor that increased during COVID-19 and an increase in selfreported child abuse was found for parents experiencing heightened stressors (Lawson et al., 2020).

It is important to note that alongside the worrisome decrease in $\mathrm{CM}$ reports and a significant increase in risk factors for $\mathrm{CM}$, several studies have illustrated an increase in children's display of stress (Jiao et al., 2020), their reports on experienced violence to helplines (Petrowski et al., 2020) as well as an increase in children's physical injuries referred to hospital emergency units (Kovler et al., 2020).

The initial data from the past year of the pandemic raises a discussion regarding the regression of prevention efforts during this time. We argue that COVID-19

Carmit Katz

drckatz@gmail.com

1 Bob Shapell School of Social Work, Tel Aviv University, Ramat Aviv, 69978 Tel Aviv, Israel 
reverted any progress of prevention efforts. Furthermore, during the pandemic, most of the various systems' resources and responses were dedicated solely to the traditional child protective model of CM, meaning its identification and investigation.

We believe that this regression is embedded in the general context of a diminished focus on children's rights worldwide during the pandemic. From this, three main globally harmful aspects are derived: the shutdown of formal systems and limited access to resources for children and their families; the impact of COVID-19 on social contexts, with social distancing generating social alienation and increased racism; and increased inequality.

\section{The Neglect of Children's Rights by Governments and Policy-makers}

While previous studies have indicated how the children's rights movement provided a grounded rationale for a public health approach in the prevention of CM (Prinz, 2016), the focus of policy-makers during COVID-19 was to limit the spread of the virus. This resulted in health restrictions with a blind spot for children's basic rights (e.g., Katz \& Cohen, 2020) and the four related principles: non-discrimination, the best interests of the child, the right to survival and development, and the views of the child (Children's Rights Alliance, 2021).

The implementation of health restrictions without any consideration for children's rights is exemplified in the implementation of a rapid return to home policy for children in care in various countries, which left little time for proper preparation of the children and their families. This raised concerns among practitioners of non-government organizations, as some children returned to unsafe environments and could not be monitored (Goldman et al., 2020; Wilke et al., 2020).

Another example is the switch to remote learning without safeguarding children's right to education. Some children might struggle more than others with remote learning (Drane et al., 2020). It might be that these children have mental, emotional, or high learning needs that their parents are not equipped to fulfill in place of school staff (Masonbrink \& Hurley, 2020). Furthermore, they could be facing other challenges to educational engagement such as crowded homes with multiple children needing to use a single computer (Rabinovitch, 2020; Schneider, 2020) or psychosocial threats in the home environment (Scheer \& Laubenstein, 2021). Others might not even have access to computers and the internet due to low income (Masonbrink \& Hurley, 2020), homelessness (Schneider, 2020), or cultural norms that do not allow the use of the internet (Nachshoni, 2020).

The impact of the pandemic extends well beyond the damage done directly to children's routines. Economic hardship, for example, has resulted in an increase in child labor and the sexual exploitation of children (Larmar et al., 2020). Simultaneously, there has been a lack of focus on the impact of COVID-19 on children. Recent reports estimated that, as of February 2021, as many as 37,300 children in the USA aged 0 to 17 years have lost at least one parent due to COVID-19. This is an increase of 17.5 to $20.2 \%$ (Kidman et al., 2021) compared to pre-COVID rates of parental loss. This means that during the pandemic, children worldwide were not provided with their most basic rights while living in escalating toxic environments. 


\section{The Shutdown of Formal Systems}

The outbreak of COVID-19 was followed by the implementation of various health restrictions, such as social distancing and lockdowns, which included limiting the operation or shutting down many formal systems in children's lives, such as schools. This created a situation in which children's access to mandated reporters was greatly reduced. Various countries severely limited community services and institutions (e.g., Katz \& Cohen, 2020) responsible for fulfilling many children's needs (Bérubé et al., 2020). The mandated restrictions highly affected families' abilities to benefit from community resources (Campbell, 2020), such as nonurgent healthcare (Wong et al., 2020) and social services (Katz \& Cohen, 2020).

The closure of schools appears to have had devastating results in this regard. Schools are a central facet of children's daily routines (Letzel et al., 2020). They can be a safe haven for children suffering from abuse and neglect at home (Bartholet, 2020), a place to ask for support, or their main source of a hot meal (Cardoso et al., 2019). As such, it has been argued that prolonged social isolation and school closures during COVID-19 might have led to serious ramifications for children's wellbeing, for example, regarding their mental health (Lee, 2020). Previous research has found limited interaction and communication with school staff to be linked to changes in $\mathrm{CM}$ report rates. Hence, during the pandemic, child educators are the mandated reporters who have been found to have the highest decrease in CM report rates (Baron et al., 2020). Additionally, findings have consistently pointed to a drop in CM reports during school closures, with the largest drop from informants from educational systems (Baron et al., 2020).

This limited access has also affected child protection services, with workers reporting a change of focus in their work, as child protection became second priority to fulfilling families' basic needs (Toros \& Falch-Eriksen, 2020). In this reality, the practice of child protection might be reduced to the very basic principles of child protection, such as identifying and investigating suspected abuse, with limited proactive child protection. Although essential to the protection of children, these practices done in isolation represent a regression from proactively preventing abuse to only addressing its consequences.

Although some digital interventions have been developed and implemented (Honda et al., 2020), social services workers have expressed mixed opinions about family engagement and improvement levels (Self-Brown et al., 2020). It has been argued that face-to-face meetings are irreplaceable (Jentsch \& Schnock, 2020). Consequently, child protection service workers have mentioned the lack of physical access to families as a challenge in protecting children in need.

Additionally, child protection services face various challenges in adapting CM prevention to the COVID-19 reality. A recent study examined the implementation of the Safe-Care preventive initiative during the pandemic in an online platform (Self-Brown et al., 2020). Along with recognizing the success of this attempt, the researchers indicated that this solution was only relevant to families with access to computers and the internet, which is not the reality for many children and their families across the globe. 


\section{The Pandemic's Impact on Communities and Social Interactions}

The efforts to restrict the spread of the virus, mainly through lockdowns and social distancing, has compromised community social cohesion, physically separated community members, and might have acted as a barrier to the ability of communities to support families in a time of crisis and protect children from maltreatment (Nay, 2020). This led to two potential detrimental outcomes for families. First, parents' ability to rely on informal support systems for childcare, such as extended family, may have been compromised. Second, children's visibility to others outside the family home was decreased.

Previous literature has established the link between social isolation and CM through consistent empirical findings (for review, see Ridings et al., 2017) First, isolation might damage protective neighborhood-level factors (e.g., Leventhal \& Brooks-Gunn, 2000; Ross \& Mirowsky, 2009), such as collective efficacy and neighborhood cohesion (Coleman, 1988; Coulton et al., 2007; Putnam, 2001; Sampson \& Morenoff, 2004; Sampson et al., 1997). These factors have been previously found to be associated with outcomes such as CM rates (e.g., Molnar et al., 2016), parenting competence (Davidson Arad et al., 2020), and children's safety and wellbeing (for reviews, see Coulton et al., 2007; Maguire-Jack, 2014).

Additionally, the forced shutdowns and increased distress within the family unit (e.g., Lee et al., 2021) may have resulted not only in social distancing but also social alienation. In many ways, the pandemic has been an economic crisis. Therefore, the outcome has been that many people worldwide are competing for limited resources. Previous studies have indicated the enormous impact that communities, social cohesion, and social competence have on children and their safety. However, it is now clear that there is much more to do to decrease the adverse impact of the pandemic on communities and social interactions to create safe and nurturing environments for children.

\section{The Crucial Role of Intersectionality in Preventing CM}

All aspects of identity, including socio-economic factors and cultural norms, can impact wellbeing, particularly in relation to the larger societal context and access to government support, which is crucial to $\mathrm{CM}$ prevention. We are now witnessing the residual effects of the COVID-19 crisis on families worldwide. One central issue is that some communities have suffered from the rise in racism and violence, with immigrants, asylum seekers, and other minorities being blamed for the spread of the virus (UNICEF, 2020a, b), a perception that has been strengthened by the media and politicians (Liu \& Modir, 2020). This could also put children's wellbeing at risk. A recent study has found that Chinese-American parents' exposure to racism during COVID-19 was linked to poorer mental health among their children (Cheah et al., 2020).

Additionally, COVID-19 restrictions have caused many parents to struggle in meeting their children's basic needs (Conrad-Hiebner \& Byram, 2020). Some families, for example, have resorted to child labor to survive, as their country does not offer unemployment financial aid or social security (e.g., Nepal; Larmar et al., 2020). 
COVID-19 has deepened the existing inequality in other aspects (Akseer et al., 2020), such as access to food (Kassa \& Grace, 2020), education, and healthcare (Katz et al., 2020; Molnar et al., 2021), all of which could result in higher rates of COVID-19 infection and death tolls (Shadmi et al., 2020). This may lead to a shift of vulnerable communities' resources and focus from child protection to physical survival.

In a recent framework suggested by a group of international scholars (Katz et al, 2020), it was suggested that a framework including intersectionality must be disseminated into policy efforts to avoid the escalation of endangering children's lives and safety during a pandemic. In addition, the researchers illustrated how social alienation and escalating racism targeted children from adverse contexts, which only further hampered their safety.

\section{Conclusions}

The COVID-19 pandemic has amplified perilous conditions for children, families, and communities with fewer resources. Approaches of prevention, especially in times of a worldwide pandemic, stress that context must inform the paradigm, thereby addressing the crucial role of intersectionality and equality, which is essential to carry out effective prevention.

Prevention cannot happen in a vacuum. In order to prevent CM, children's needs must be seen. They need to be provided with their basic rights and working systems that can see, approach, and communicate with them, but also with one another. They also need strong communities around them, where people will care for them and be willing to act to advance their safety. However, none of these conditions was possible in COVID-19, but rather the contrary. While policy-makers and the public worldwide were dedicating their attention and resources to mitigate the virus, children, their rights, and their protection from CM were neglected.

A year into the pandemic, with evidence of the adverse impact on millions of children across the globe, it seems that there was a rapid process of digression regarding CM prevention and advancing children's safety. Even when resources targeted $\mathrm{CM}$, they were dedicated to the basic steps of identification and investigation. This signals the necessity of a movement that includes the international community in an attempt to implement a public health approach to CM in addition to the traditional strategy of child protection. In many ways, the pandemic acted as a magnifier of child protection services' strengths and weaknesses, leaving us only with practices that we are strong at as a worldwide community-identification and investigation of CM. Therefore, it is not surprising how these are the practices that were continued during the pandemic. The pandemic illustrated that CM prevention is still far from being a part of our daily lives; hence, it completely disappeared during COVID-19. Our mission now, as a community of scholars dedicated to the protection of children from maltreatment, is to do whatever is needed to integrate prevention strategies as a basic practice in our daily lives and public agenda. Maybe then, when future worldwide crises will arrive, there will be better mechanisms in place to see our children, ensure their rights, and advance their safety. 


\section{References}

Akseer, N., Kandru, G., Keats, E. C., \& Bhutta, Z. A. (2020). COVID-19 pandemic and mitigation strategies: Implications for maternal and child health and nutrition. The American Journal of Clinical Nutrition, 112(2), 251-256. https://doi.org/10.1093/ajcn/nqaa171.

Baron, E. J., Goldstein, E. G., \& Wallace, C. T. (2020). Suffering in silence: How COVID-19 school closures inhibit the reporting of child maltreatment. Journal of Public Economics, 190, 104258. https:// doi.org/10.1016/j.jpubeco.2020.104258.

Bartholet, E. (2020). Homeschooling: Parent rights absolutism vs. child rights to education \& protection. Arizona Law Review, 62(1), 1-80.

Bérubé, A., Clément, M. È., Lafantaisie, V., LeBlanc, A., Baron, M., Picher, G., Turgeon, J., RuizCasares, M., Lacharité, C. (2020). How societal responses to COVID-19 could contribute to child neglect. Child Abuse Negl, 104761. https://doi.org/10.1016/j.chiabu.2020.104761.

Campbell, A. M. (2020). An increasing risk of family violence during the Covid-19 pandemic: Strengthening community collaborations to save lives. Forensic Science International: Reports, 2, 100089. https://doi.org/10.1016/j.fsir.2020.100089.

Cardoso, S. G., Truninger, M., Ramos, V., \& Augusto, F. R. (2019). School meals and food poverty: Children's views, parents' perspectives and the role of school. Children \& Society, 33(6), 572-586. https://doi.org/10.1111/chso.12336.

Cheah, C. S., Wang, C., Ren, H., Zong, X., Cho, H. S., \& Xue, X. (2020). COVID-19 racism and mental health in Chinese American families. Pediatrics, 146(5) https://doi.org/10.1542/peds.2020-021816.

Children's Rights Alliance. (2021). What are children's rights? https://childrensrights.ie/childrens-rightsireland/childrens-rights-ireland.

Coleman, J. S. (1988). Social capital in the creation of human capital. American Journal of Sociology, 94, S95-S120.

Conrad-Hiebner, A., \& Byram, E. (2020). The temporal impact of economic insecurity on child maltreatment: A systematic review. Trauma, Violence, \& Abuse, 21(1), 157-178. https://doi.org/10.1177/ 1524838018756122.

Coulton, C. J., Crampton, D. S., Irwin, M., Spilsbury, J. C., \& Korbin, J. E. (2007). How neighborhoods influence child maltreatment: A review of the literature and alternative pathways. Child Abuse \& Neglect, 31(11-12), 1117-1142. https://doi.org/10.1016/j.chiabu.2007.03.023.

Davidson Arad, B., McLeigh, J. D., \& Katz, C. (2020). Perceived collective efficacy and parenting competence: The roles of quality of life and hope. Family Process, 59(1), 273-287. https://doi.org/10. 1111/famp.12405.

Drane, C., Vernon, L., \& O'Shea, S. (2020). The impact of 'learning at home' on the educational outcomes of vulnerable children in Australia during the COVID-19 pandemic. Literature Review Prepared by the National Centre for Student Equity in Higher Education. Curtin University, Australia

Goldman, P. S., van Ijzendoorn, M. H., Bakermans-Kranenburg, M. J., Bradford, B., Christopoulos, A., Cuthbert, C., Duchinsky, R., Fox, N. A., Gunnar, M. R., Ibrahim, R. W., Johnson, D., Kusumaningrum, S., Lim Ah Ken, P., Mwangangi, F. M., Nelson, C. A., III., Ott, E. M., Reijman, S., Zeanah, C. H., \& Sonuga-Barke, E. J. S. (2020). The implications of COVID-19 for the care of children living in residential institutions. The Lancet Child \& Adolescent Health, 4(6), e12. https://doi.org/10. 1016/S2352-4642(20)30130-9.

Honda, C., Yoshioka-Maeda, K., \& Iwasaki-Motegi, R. (2020). Child abuse and neglect prevention by public health nurses during the COVID-19 pandemic in Japan. Journal of Advanced Nursing, 76(1), 2792-2793. https://doi.org/10.1111/jan.14526.

Jentsch, B., \& Schnock, B. (2020). Child welfare in the midst of the coronavirus pandemic-Emerging evidence from Germany. Child Abuse \& Neglect, 110, 104716. https://doi.org/10.1016/j.chiabu. 2020.104716.

Jiao, W. Y., Wang, L. N., Liu, J., Fang, S. F., Jiao, F. Y., Pettoello-Mantovani, M., \& Somekh, E. (2020). Behavioral and emotional disorders in children during the COVID-19 epidemic. The Journal of Pediatrics, 221, 264-266. https://doi.org/10.1016/j.jpeds.2020.03.013.

Kassa, M. D., \& Grace, J. M. (2020). Race against death or starvation? COVID-19 and its impact on African populations. Public Health Reviews, 41(1), 1-17. https://doi.org/10.1186/s40985-020-00139-0.

Katz, C., \& Cohen, N. (2020). Invisible children and non-essential workers: Child protection during COVID-19 in Israel according to policy documents and media coverage. Child Abuse \& Neglect, 104770. https://doi.org/10.1016/j.chiabu.2020.104770. 
Katz, C., Priolo Filho, S. R., Korbin, J., Bérubé, A., Fouche, A., Haffejee, S., Kaawaa-Mafigiri, D., Maguire-Jack, K., Muñoz, P., Spilsbury, J., Tarabulsy, G., Tiwari, A., Thembelkile Levine, D., Truter, E., \& Varela, N. (2020). Child maltreatment in the time of the COVID-19 pandemic: A proposed global framework on research, policy and practice. Child Abuse \& Neglect, 104824. https:// doi.org/10.1016/j.chiabu.2020.104824.

Kidman, R., Margolis, R., Smith-Greenaway, E., Verdery, A. M. (2021). Estimates and projections of COVID-19 and parental death in the US. JAMA Pediatrics, E1-E2. https://doi.org/10.1001/jamap ediatrics.2021.0161.

Kovler, M. L., Ziegfeld, S., Ryan, L. M., Goldstein, M. A., Gardner, R., Garcia, A. V., \& Nasr, I. W. (2020). Increased proportion of physical child abuse injuries at a level I pediatric trauma center during the Covid-19 pandemic. Child Abuse \& Neglect, 104756.| https://doi.org/10.1016/j.chiabu.2020. 104756.

Larmar, S., Sunuwar, M., Sherpa, H., Joshi, R., \& Jordan, L. P. (2020). Strengthening community engagement in Nepal during COVID-19: Community-based training and development to reduce child labour. Asia Pacific Journal of Social Work and Development, 31(1-2), 23-30. https://doi.org/10. 1080/02185385.2020.1833749.

Lawson, M., Piel, M. H., \& Simon, M. (2020). Child maltreatment during the COVID-19 pandemic: Consequences of parental job loss on psychological and physical abuse towards children. Child Abuse \& Neglect, 110(2), 104709. https://doi.org/10.1016/j.chiabu.2020.104709.

Lee, J. (2020). Mental health effects of school closures during COVID-19. The Lancet Child \& Adolescent Health, 4(6), 421. https://doi.org/10.1016/S2352-4642(20)30109-7.

Lee, S. J., Ward, K. P., Lee, J. Y., \& Rodriguez, C. M. (2021). Parental social isolation and child maltreatment risk during the COVID-19 pandemic. Journal of Family Violence, 1-12.] https://doi.org/10. 1007/s10896-020-00244-3.

Letzel, V., Pozas, M., \& Schneider, C. (2020). Energetic students, stressed parents, and nervous teachers: A comprehensive exploration of inclusive homeschooling during the COVID-19 crisis. Open Education Studies, 2(1), 159-170. https://doi.org/10.1515/edu-2020-0122.

Leventhal, T., \& Brooks-Gunn, J. (2000). The neighborhoods they live in: The effects of neighborhood residence on child and adolescent outcomes. Psychological Bulletin, 126(2), 309-337. https://doi. org/10.1037/0033-2909.126.2.309.

Liu, S. R., \& Modir, S. (2020). The outbreak that was always here: Racial trauma in the context of COVID-19 and implications for mental health providers. Psychological Trauma: Theory, Research, Practice, and Policy, 12(5), 439-442. https://doi.org/10.1037/tra0000784.

Maguire-Jack, K. (2014). Multilevel investigation into the community context of child maltreatment. Journal of Aggression, Maltreatment \& Trauma, 23(3), 229-248. https://doi.org/10.1080/10926771. 2014.881950 .

Masonbrink, A. R., \& Hurley, E. (2020). Advocating for children during the COVID-19 school closures. Pediatrics, 146(3)/ https://doi.org/10.1542/peds.2020-1440.

Molnar, B. E., Goerge, R. M., Gilsanz, P., Hill, A., Subramanian, S. V., Holton, J. K., et al. (2016). Neighborhood-level social processes and substantiated cases of child maltreatment. Child Abuse \& Neglect, 51, 41-53. https://doi.org/10.1016/j.chiabu.2015.11.007.

Molnar, B. E., Scoglio, A. A. J., \& Beardslee, W. R. (2021) Community-level prevention of childhood maltreatment: Next steps in a world with COVID-19. International Journal on Child Maltreatment: Research, Policy and Practice, 3, 467-481. https://doi.org/10.1007/s42448-020-00064-4.

Nachshoni, K. (2020). ידרחה רזגמב קרחרמ הדימל 11 [Dופלט רק לע םידלי [Distance learning in the ultra-Orthodox sector: 11 children on a telephone line]. Ynet. https://www.ynet.co.il/articles/ 0,7340,L-5717962,00.html.

Nay, O. (2020). Can a virus undermine human rights? The Lancet Public Health, 5(5), e238-e239. https://doi.org/10.1016/S2468-2667(20)30092-X.

Petrowski, N., Cappa, C., Pereira, A., Mason, H., \& Daban, R. A. (2020). Violence against children during COVID-19 Assessing and understanding change in use of helplines. Child Abuse \& Neglect, 104757. https://doi.org/10.1016/j.chiabu.2020.104757.

Prinz, R. J. (2016). Parenting and family support within a broad child abuse prevention strategy: Child maltreatment prevention can benefit from public health strategies. Child Abuse \& Neglect, 51, 400406. https://doi.org/10.1016/j.chiabu.2015.10.015.

Proulx, K., Lenzi-Weisbecker, R., Rachel, R., Hackett, K., Cavallera, V., Daelmans, B., \& Dua, T. (2021). Responsive caregiving, opportunities for early learning, and children's safety and security during COVID-19: A rapid review. medRxivhttps://doi.org/10.1101/2021.02.10.21251507. 
Putnam, R. (2001). Social capital: Measurement and consequences. Canadian Journal of Policy Research, 2(1), 41-51.

Rabinovitch, M. (2020). End-measure availability and Internet connection for children for remote learning]. The Research and Information Center - The Knesset. https://fs.knesset.gov.i1/23/Committees/ 23_cs_bg_578268.pdf.

Ridings, L. E., Beasley, L. O., \& Silovsky, J. F. (2017). Consideration of risk and protective factors for families at risk for child maltreatment: An intervention approach. Journal of Family Violence, 32(2), 179-188. https://doi.org/10.1007/s10896-016-9826-y.

Rodriguez, C. M., Lee, S. J., Ward, K. P., \& Pu, D. F. (2020). The perfect storm: Hidden risk of child maltreatment during the COVID-19 pandemic. Child Maltreatment, 1077559520982066 https://doi. org/10.1177/1077559520982066.

Ross, C. E., \& Mirowsky, J. (2009). Neighborhood disorder, subjective alienation, and distress. Journal of Health and Social Behavior, 50(1), 49-64. https://doi.org/10.1177/002214650905000104.

Russell, B. S., Hutchison, M., Tambling, R., Tomkunas, A. J., \& Horton, A. L. (2020). Initial challenges of caregiving during COVID-19: Caregiver burden, mental health, and the parent-child relationship. Child Psychiatry \& Human Development, 51(5), 671-682. https://doi.org/10.1007/ s10578-020-01037-x.

Sampson, R. J., \& Morenoff, J. D. (2004). Spatial (dis) advantage and homicide in Chicago neighborhoods. In M. F. Goodchild, \& D. G. Janelle (Eds.), Spatially integrated social science (pp. 145-170) Oxford University Press.

Sampson, R. J., Raudenbush, S. W., \& Earls, F. (1997). Neighborhoods and violent crime: A multilevel study of collective efficacy. Science, 277(5328), 918-924. https://doi.org/10.1126/science.277.5328. 918.

Scheer, D., \& Laubenstein, D. (2021). The impact of COVID-19 on mental health and psycho-social conditions of students with and without special educational needs in emotional and behavioral disorders in Germany. EdArXiv.

Schneider J. (2020). Perspective: How COVID-19 laid bare the vast inequities in U.S. public education. Washington Post https://www.washingtonpost.com/education/2020/04/14/how-covid-19-has-laidbare-vast-inequities-us-public-education/.

Self-Brown, S., Reuben, K., Perry, E. W., Bullinger, L. R., Osborne, M. C., Bielecki, J., \& Whitaker, D. (2020). The impact of COVID-19 on the delivery of an evidence-based child maltreatment prevention program: Understanding the perspectives of SafeCare ${ }^{\circledR}$ providers. Journal of Family Violence. https://doi.org/10.1007/s10896-020-00217-6.

Shadmi, E., Chen, Y., Dourado, I., Faran-Perach, I., Furler, J., Hangoma, P., Hanvoravongchai, P., Obando, C., Petrosyan, V., Rao, K. D., Ruano, A. L., Shi, L., Eugenio de Souza, L., Spitzer-Shohat, S., Sturgiss, E., Suphanchaimat, R., Villar Uribe, M., \& Willems, S. (2020). Health equity and COVID-19: Global perspectives. International Journal for Equity in Health, 19, 104. https://doi. org/10.1186/s12939-020-01218-z.

Toros, K., \& Falch-Eriksen, A. (2020). A child's right to protection during the COVID-19 crisis: An exploratory study of the child protective services of Estonia. Children and Youth Services Review, 119, 105568. https://doi.org/10.1016/j.childyouth.2020.105568.

UNICEF. (2020a). Coronavirus (COVID-19) global response. https://www.unicef.org/media/82626/file/ 2020-HAC-CoronaVirus-updated-07.21.pdf.

UNICEF. (2020b). Global risk communication and community engagement strategy. https://www.unicef.org/ media/90706/file/COVID-19-Global-Risk-Communication-and-Community-Engagement-Strategy.pdf.

Wilke, N. G., Howard, A. H., \& Goldman, P. (2020). Rapid return of children in residential care to family as a result of COVID-19: Scope, challenges, and recommendations. Child Abuse \& Neglect, 110, 104712. https://doi.org/10.1016/j.chiabu.2020.104712.

Wong, C. A., Ming, D., Maslow, G., \& Gifford, E. J. (2020). Mitigating the impacts of the COVID-19 pandemic response on at-risk children. Pediatrics, 146(1)/ https://doi.org/10.1542/peds.2020-0973.

Wu, Q., \& Xu, Y. (2020). Parenting stress and risk of child maltreatment during the COVID-19 pandemic: A family stress theory-informed perspective. Developmental Child Welfare, 2(3), 180-196. https://doi.org/10.1177/2516103220967937.

Publisher's Note Springer Nature remains neutral with regard to jurisdictional claims in published maps and institutional affiliations. 